\title{
Penerapan Pendekatan Saintifik dengan Media Flashcard untuk Meningkatkan Hasil Belajar IPS tentang Perjuangan Para Pejuang pada Masa Penjajahan Belanda dan Jepang Di Kelas V SD Negeri 1 Selang Tahun Ajaran 2017/2018
}

\author{
1,2,3 Universitas Sebelas Maret \\ dewiastuti966@gmail.com
}

Dewi Astuti ${ }^{1}$, M. Chamdani ${ }^{2}$, Rokhmaniyah ${ }^{3}$

\section{Article History \\ accepted 01/02/2019}

approved 01/03/2019 published 01/04/2019

\begin{abstract}
The objective of this research is to improve social science learning about the struggle of warriors in Dutch and Japan colonialism. This research is a collaborative Classroom Action Research (CAR) conducted within two cycles and subject of the research is fifth grade students. Sources of data were derived from teacher, students, and document. Techniques of analysing data in this research were data reduction, data display, and verification. The result of this research is the implementation of scientific approach using flashcard can improve social science learning about the struggle of warriors in Dutch and Japan colonialism for the fifth grade students of SD Negeri 1 Selang in the academic year of 2017/2018. It was proven by the increase of learning outcomes percentage in the first cycle $62.82 \%$ and in the second cycle $86.89 \%$. The conclusion of this research is the implementation of scientific approach using flashcard can improve social science learning about the struggle of warriors in Dutch and Japan colonialism.
\end{abstract}

Keywords: scientific approach, flashcard media, social science learning

\section{Abstrak}

Tujuan penelitian ini yaitu meningkatkan hasil belajar IPS tentang perjuangan para pejuang pada masa penjajahan Belanda dan Jepang. Penelitian ini merupakan penelitian tindakan kelas (PTK) kolaboratif melalui dua siklus dengan subjek penelitian siswa kelas V. Sumber data penelitian ini adalah guru, siswa dan dokumen. Teknik analisis data pada penelitian ini yaitu reduksi data, penyajian data dan verification. Hasil penelitian ini menunjukkan bahwa penerapan pendekatan saintifik dengan media flashcard dapat meningkatkan hasil belajar IPS tentang tentang perjuangan para pejuang pada masa penjajahan Belanda dan Jepang di kelas V SD Negeri 1 Selang tahun ajaran 2017/2018. Hal itu dibuktikan dengan perolehan persentase ketuntasan siswa pada siklus I sebesar $62,82 \%$ dan pada siklus II meningkat menjadi $86,54 \%$. Simpulan dari penelitian ini adalah penerapan pendekatan saintifik dengan media flashcard dapat meningkatkan hasil belajar IPS tentang perjuangan para pejuang pada masa penjajahan Belanda dan Jepang.

Kata Kunci: Pendekatan Saintifik, Flashcard, Hasil Belajar IPS 


\section{PENDAHULUAN}

Pendidikan merupakan kebutuhan utama dalam menjamin kelangsungan hidup manusia. Keberhasilan suatu tujuan pendidikan, tergantung pada usaha sadar yang dilakukan keluarga, masyarakat, dan pemerintah melalui kegiatan bimbingan, pengajaran, dan latihan yang berlangsung di lingkungan sekolah dan masyarakat. Wujud usaha sadar itu dapat dilakukan melalui pembelajaran dimana ada penddik yang melayani siswanya melakukan kegiatan belajar dan menilai siswa sesuai dengan ketentuan (Sagala, 2013:4). Tolak ukur dari tercapainya tujuan tersebut dapat dilihat dari hasil belajar siswa terhadap suatu materi yang dipelajari. IPS adalah ilmu pengetahuan yang dikaji dari beberapa disiplin ilmu humaniora yang kegiatannya berada di sekitar manusia yang dikemas secara ilmiah untuk memperdalam pengetahuan siswa pada jenjang dasar dan menengah (Susanto, 2016: 140). Somantri berpendapat bahwa pendidikan IPS adalah pemilihan berbagai disiplin ilmu-ilmu sosial dan humaniora, serta kegiatan dasar manusia yang diorganisasikan dan disajikan secara ilmiah dan pedagogis/psikologis untuk tujuan pendidikan (Sapriya, 2016:11).

Berdasarkan hasil observasi dan wawancara yang dilakukan oleh peneliti terhadap guru kelas V SD Negeri 1 Selang pada hari Kamis 31 Agustus 2017 diperoleh keterangan bahwa pada saat pembelajaran sudah menggunakan media, akan tetapi keaktifan siswa untuk mengajukan pertanyaan dan pendapat jarang terlihat. Selain itu, juga dikarenakan oleh keadaan siswa yang sulit menerima materi pelajaran dan juga banyak siswa yang senang berbicara dengan teman sebangkunya, sehingga membuat suasana kelas tidak kondusif. Hasil analisis nilai Ulangan Semester II tahun ajaran 2016/2017 menunjukkan, dari 20 siswa kelas V SD Negeri 1 Selang yang terdiri dari 9 siswa laki-laki dan 11 siswa perempuan, hanya ada 8 siswa yang mencapai Kriteria Ketuntasan Minimal $(\mathrm{KKM})=61$.

Menurut hasil wawancara terhadap guru SD Kelas V SD Negeri 1 Selang mengenai pembelajaran IPS, menunjukkan bahwa perlu adanya motivasi belajar IPS untuk siswa dapat benar-benar memahami materi pembelajaran IPS yang disampaikan oleh guru dan siswa merasa kesulitan untuk menguasai materi IPS terutama yang berkaitan dengan sejarah.

Kondisi di atas menjadi fokus perhatian bagi peneliti, bahwa keberhasilan pembelajaran sangat dipengaruhi oleh cara guru menyampaikan materi. Pada proses pembelajaran, guru kelas V SD Negeri 1 Selang belum menggunakan pendekatan pembelajaran yang inovatif dan media yang digunakan hanya gambar yang tersedia di buku sumber saja.

Berdasarkan kenyataan di atas, peneliti menawarkan solusi pembelajaran yang melibatkan siswa aktif, meningkatkan minat belajar siswa, dan mengkonkretkan hal-hal yang abstrak bagi siswa dalam memahami materi IPS melalui penerapan pendekatan saintifik dengan media flashcard.

Pendekatan saintifik adalah proses pembelajaran yang sengaja disusun untuk mengarahkan siswa secara aktif membangun prinsip atau hukum dan konsep melalui beberapa tahap yaitu mengamati untuk menemukan masalah, merumuskan masalah, mengajukan hipotesis, mencari informasi kemudian menganalisisnya, menyimpulan dan mengomunikasikan prinsip atau hukum dan konsep tersebut (Hosnan, 2016: 32). Pendekatan saintifik juga diartikan sebagai pendekatan pembelajaran yang mengarahkan siswa untuk melakukan proses pencarian pengetahuan tentang materi pelajaran dengan cara menerapkan kegiatan layaknya seorang ilmuwan dengan segala proses sainsnya dalam penyelidikan ilmiah artinya siswa dibimbing untuk menemukan sendiri berbagai konsep, fakta, dan nilai-nilai baru yang diperlukan untuk kehidupannya Ine (2015: 271).

Kata media berasal dari bahasa Latin dan merupakan "bentuk jamak dari kata medium yang secara harfiah berarti perantara atau pengantar" (Sadiman, dkk, 2014: 6). Flashcard biasanya berukuran $8 \times 12 \mathrm{~cm}$, atau dapat disesuaikan dengan besar 
kecilnya kelas yang dihadapi (Arsyad, 2016: 115). Flashcard merupakan serangkaian pesan yang disajikan dengan adanya keterangan pada setiap gambar (Susilana dan Riyana, 2007: 93).

Berdasarkan pemaparan mengenai pendekatan saintifik dan media flashcard, dapat disimpulkan bahwa penerapan pendekatan saintifik dengan media flashcard adalah kartu belajar yang berukuran $8 \times 12 \mathrm{~cm}$ yang berisi serangkaian pesan yang disajikan dengan adanya keterangan pada setiap gambar melalui tahap mengamati, menanaya, mengumpulkan informasi, menalar/mengolah informasi, dan mengomunikasikan yang menggunakan flashcard dengan langkah-langkah sebagai berikut: 1) mengamati dengan media flashcard, 2) menanya, 3) mengumpulkan informasi dengan media flashcard, 4) menalar/mengolah informasi, 5) mengomunikasikan.

Rumusan masalah dalam penelitian ini yaitu apakah penerapan pendekatan saintifik dengan media flashcard dapat meningkatkan hasil belajar IPS tentang perjuangan para pejuang pada masa penjajahan Belanda dan Jepang.

Penelitian ini bertujuan untuk meningkatkan hasil belajar IPS tentang perjuangan para pejuang pada masa penjajahan Belanda dan Jepang.

\section{METODE}

Penelitian ini dilaksanakan di kelas V SD Negeri 1 Selang, Kecamatan Kebumen, Kabupaten Kebumen. Subjek penelitian ini adalah 26 siswa yang terdiri dari 13 siswa laki-laki dan 13 siswa perempuan. Penelitian ini dilaksanakan mulai bulan Agustus 2017 sampai dengan bulan Februari 2018.

Alat pengumpulan data dalam penelitian ini yaitu instrumen tes yang berupa lembar evaluasi dan instrumen nontes yang berupa lembar observasi dan pedoman wawancara. Penelitian ini merupakan penelitian tindakan kelas kolaboratif antara peneliti sebagai perencana dan guru kelas $\mathrm{V}$ sebagai pelaksana tindakan. Observer pada penelitian ini adalah 3 orang teman sejawat dan peneliti sendiri. Data dari hasil penelitian berupa hasil observasi terhadap penerapan pendekatan saintifik dengan media flashcard oleh guru, respon siswa terhadap pembelajaran yang menerapkan pendekatan saintifik dengan media flashcard, dan hasil evaluasi siswa. Uji validitas data menggunakan triangulasi yang merupakan penggabungan dari berbagai sumber data dan teknik pengumpulan data yang telah ada (Sugiyono, 2016: 241). Penelitian ini menggunkan triangulasi sumber dan teknik. Data tersebut kemudian dianalisis dengan tiga tahapan: (1) reduksi, (2) penyajian data, (3) verification.

Indikator kinerja penelitian baik dari segi proses oleh guru dan siswa maupun hasil pelaksanaan pembelajaran melalui penerapan pendekatan saintifik dengan multimedia sebesar $85 \%$. KKM hasil belajar yang ditargetkan pada penelitian ini yaitu 70.

Penelitian dilaksanakan selama 2 siklus. Setiap siklus terdiri dari 3 pertemuan dengan 4 tahapan sesuai pendapat Arikunto (2013: 131) yaitu (1) perencanaan, (2) pelaksanaan, (3) pengamatan, dan (4) refleksi.

Pada pelaksanaannya, tahapan ini selalu berhubungan dan berkelanjutan dalam prosesnya, serta mengalami perbaikan-perbaikan sesuai dengan hasil observasi dan refleksi hingga memenuhi hasil atau tujuan yang diharapkan.

\section{HASIL DAN PEMBAHASAN}

Data hasil observasi dari tiga observer terkait penerapan pendekatan saintifik dengan media flashcard. 
Volume 7 Nomor 1 Tahun 2019

Tabel 1. Hasil Observasi terhadap Guru dan Siswa

\begin{tabular}{clrr}
\hline Siklus & Pembanding & Guru & Siswa \\
\hline \multirow{2}{*}{ I } & Rata-rata & 2,98 & 2,94 \\
\cline { 2 - 4 } & Persentase & 74,35 & 73,55 \\
\hline \multirow{2}{*}{ II } & Rata-rata & 3,4 & 3,402 \\
\cline { 2 - 4 } & Persentase & 85 & 85,05 \\
\hline
\end{tabular}

Berdasarkan tabel di atas, dapat diketahui bahwa penerapan pendekatan saintifik dengan media flashcard oleh guru mengalami peningkatan dari siklus I ke siklus II. Peningkatan persentase juga dapat dilihat dari hasil observasi terhadap siswa dari siklus I ke siklus II. Persentase guru dan siswa pada siklus II telah menunjukkan bahwa indikator kinerja yang ditargetkan telah tercapai.

Pembelajaran pada siklus I dilaksanakan melalui 3 pertemuan dengan indikator menceritakan penyebab jatuhnya daerah Nusantara ke dalam kekuasaan Pemerintah Belanda; mengidentifikasi tokoh-tokoh Belanda pada masa penjajahan, menjelaskan sistem kerja paksa, tanam paksa, dan penarikan pajak; menyebutkan tokoh-tokoh daerah yang berjuang melawan Belanda; mendeskripsikan riwayat para tokoh daerah dalam upaya mengusir penjajah; menceritakan perjuangan para tokoh daerah; menyimpulkan bentuk perlawanan para tokoh perjuangan; menceritakan latar belakang timbulnya pergerakan nasional; menjelaskan organisasi pergerakan nasional dan menyimpulkan peranan tokoh-tokoh pergerakan nasional. Pelaksanaan pada siklus I secara keseluruhan telah sesuai dengan skenario yang direncanakan, namun persentase rata-rata yang diperoleh guru dan siswa pada siklus I belum mencapai indikator yakni $74,35 \%$ dan $73,55 \%$. Terdapat beberapa kendala yang harus dibenahi, sehingga penelitian dilanjutkan ke siklus II.

Pembelajaran pada siklus II dilaksanakan berdasarkan hasil refleksi siklus I dengan indikator mengidentifikasi berdirinya kongres pemuda I dan kongres pemuda II, mendeskripsikan peranan tokoh dalam sumpah pemuda, menceritakan pendudukan Jepang di Indonesia, menceritakan sebab dan akibat pengerahan tenaga romusha oleh Jepang terhadap pendduk Indonesia, menceritakan dan menyebutkan tokoh daerah dalam perlawanan menentang Jepang. Hasil penelitian pada siklus II menunjukkan bahwa adanya peningkatan persentase rata-rata guru dan siswa menjadi $85 \%$ dan $85,05 \%$. Secara keseluruhan pembelajaran yang dilakukan telah sesuai dengan skenerio yang direncanakan dan kendala yang ada tidak terlalu berpengaruh negatif bagi langkah pembelajaran yang telah tersusun diskenario, sehingga peneliti mencukupkan tindakan karena persentase tersebut telah menunjukkan tercapainya indikator yang ditargetkan.

Selain hasil observasi, berikut peningkatan hasil tes evaluasi siswa pada pembelajaran melalui penerapan pendekatan saintifik dengan multimedia pada siklus I dan II.

Tabel 2. Peningkatan Hasil Belajar Antarsiklus

\begin{tabular}{ccc}
\hline \multirow{2}{*}{$\begin{array}{c}\text { Siklu } \\
\text { S }\end{array}$} & \multicolumn{2}{c}{ Ketuntasan } \\
\cline { 2 - 3 } & $\begin{array}{c}\text { Tuntas } \\
(\%)\end{array}$ & $\begin{array}{c}\text { Belum } \\
\text { Tuntas (\%) }\end{array}$ \\
\hline I & 37,18 & 62,82 \\
II & 86,11 & 13,89 \\
\hline
\end{tabular}

Berdasarkan tabel di atas, dapat dilihat dengan jelas bahwa pada siklus I persentase rata-rata ketuntasana siswa $37,18 \%$. Persentase itu belum menunjukkan tercapainya indikator yang ditargetkan, sehingg penelitian dilanjutkan ke siklus II. Pada siklus II persentase rata-rata ketuntasan siswa naik menjadi $86,11 \%$. 
Hasil penelitian ini sependapat dengan Trapsilo (2016) yang mengemukakan bahwa pendekatan saintifik dapat meningkatkan hasil belajar IPS, dengan persentase rata-rata ketuntasan $67 \%$ pada siklus I kemudian naik menjadi $86 \%$ pada siklus II, dan naik lagi menjadi 95\% pada siklus III. Pendapat yang sama juga dikemukakan oleh Fazriah (2015), dengan persentase rata-rata ketuntasan pada siklus I 76,92\% naik menjadi $80,57 \%$ pada siklus II.

\section{SIMPULAN}

Berdasarkan analisis pelaksanaan penelitian, hasil penelitian dan pembahasan maka dapat disimpulkan bahwa penerapan pendekatan saintifik dengan media flashcard dapat meningkatkan hasil belajar IPS tentang perjuangan para pejuang pada masa penjajahan Belanda dan Jepang.

Selanjutnya, dari hasil penelitian di atas, peneliti memberikan saran kepada guru untuk menjadikan pendekatan saintifik dengan media flashcard sebagai salah satu alternatif guru dalam peningkatan hasil belajar siswa. Selanjutnya saran untuk sekolah, sebaiknya menyediakan sarana pembelajaran yang lengkap untuk mendukung guru untuk meningkatkan kualitas pembelajaran. Saran yang terakhir adalah untuk pembaca atau peneliti lain, sebaiknya membuat kegiatan pembelajaran yang lebih inovatif dan kreatif sesuai dengan perkembangan ilmu pengetahuan dan teknologi.

\section{DAFTAR PUSTAKA}

Ade, I.P. (2016). Penerapan Pendekatan saintifik dengan Media Multimedia untuk Meningkatkan Hasil Belajar IPS Siswa Materi Peristiwa dan Tokoh Proklamasi Kemerdekaan Indonesia bagi Siswa Kelas V SDN 1 Pejagoan Tahun Ajaran 2015/2016, $4(3,1): 1$.

Arikunto, S. (2013). Prosedur Penelitian Suatu Pendekatan Praktik. Jakarta: Rineka Cipta.

Arsyad, A. (2016). Media Pembelajaran. Jakarta: Rajagravindo Persada.

Fazriah, W. D. (2015). Penerapan Pendekatan Saintifik dengan Penilaian Proyek untuk Meningkatkan Hasil Belajar Pengetahuan IPS dan Kemampuan Penalaran Kelas IV SD negeri 26 Pemecutan, 3 (1): 1.

Hosnan, M. (2016). Pendekatan Saintifik Dengan Kontekstual dalam Pembelajaran Abad 21 Kunci Sukses Implementasi Kurikulum 2013. Bogor: Ghalia Indonesia.

Ine, M. E. (2015). Penerapan Pendekatan Scientific untuk Meningkatkan Prestasi Belajar Siswa pada Mata Pelajaran Ekonomi Pokok Bahasan Pasar. Dalam Ali Muhson, dkk (Eds.). Prosiding Seminar Nasional Profesionalisme Pendidik dalam Dinamikan Kurikulum Pendidikan di Indonesia pada Era MEA, hIm. 269 285, FE Universitas Negeri Yogyakarta.

Riyana, C \& Susilana R. (2007). Media Pembelajaran. Bandung: Wacana Prima.

Sadiman, dkk. (2014). Media Pendidikan Pengertian, Pengembangan, dan Pemanfaatannya. Jakarta: Rajagrafindo Persada.

Sagala, S. (2013). Konsep dan Makna Pembelajaran. Bandung: Alfabeta.

Sapriya. (2016). Pendidikan IPS Konsep dan Pembelajaran. Bandung: Remaja Rosdakarya.

Sugiyono. (2016). Metode Penelitian Kuantitaif Kualitatif dan R\&D. Bandung: Alfabeta.

Susanto, A. (2016). Teori Belajar \& Pembelajaran di Sekolah Dasar. Jakarta: Prenadamedia Group.

Trapsilo, B. (2016). Penerapan Pendekatan Saintifik Untuk Meningkatkan Hasil Belajar Siswa Pada Mata Pelajaran IPS Materi Perkembangan Teknologi Kelas IV SDN Klueih 02 Bandar Batang, 2 (1): 1. 